\title{
Distributional extension for a dry forest species, Mesoscincus managuae (Dunn, 1933) (Squamata, Scincidae), on the Subhumid Caribbean versant of Honduras
}

\author{
Mario Roberto Espinal ${ }^{1}$ José Manuel Mora² $^{2}$ \\ 1 Centro Zamorano de Biodiversidad, Honduras. 2 Carrera de Gestión Ecoturística, Sede Central, Universidad Técnica Nacional, Alajuela, Costa Rica. \\ Corresponding author: José Manuel Mora, josemora07@gmail.com
}

\begin{abstract}
Mesoscincus managuae (Dunn, 1933) (Squamata, Scincidae) is a typical dry-forest species found along the Pacific versant of Central America from Guatemala to northwestern Costa Rica. Here, we report the occurrence of this species on the Caribbean versant of Honduras, specifically on the Sula Plain, Deparment of Cortés. This is a subhumid habitat similar to others in the Mesoamerican region which have comparable herpetofauna assemblages and where $M$. managuae has already been recorded.
\end{abstract}

Key words

Herpetofauna assemblages, Mesoamerican Hotspot, San Pedro Sula, subhumid habitats, Sula Plain.

Academic editor: Sebastian Lotzkat | Received 18 November 2018 | Accepted 25 February 2019 | Published 15 March 2019

Citation: Espinal MR, Mora JM (2019) Distributional extension for a dry forest species, Mesoscincus managuae (Dunn, 1933) (Squamata, Scincidae), on the Subhumid Caribbean versant of Honduras. Check List 15 (2): 269-273. https://doi.org/10.15560/15.2.269

\section{Introduction}

The Mesoamerican Hotspot is the second most diverse in the world and hosts more than 17,000 plant species, including 3,000 of them endemic (Mittermeier et al. 2004). This hotspot encompasses almost all of Central America. It is a region highly vulnerable to extreme climatic events, due to global climate change because of weather stresses, and non-climatic stresses such as effects of demographic pressure and over-exploitation of natural resources (Escobar-Anleu et al. 2018). Within this region, Honduras is projected to be among those countries most affected by climate change (TRAGSATEC 2016). Poverty of the human population and the resultant pressures on natural resources along with extreme weather events are expected to continue to increase. This means that biodiversity will become even more vulnerable (Magrin et al. 2007).

Although amphibians and reptiles are some of the best-known faunal groups in Honduras, much still remains to be known about these creatures in this country (McCranie 2018). Besides, significant habitat loss due to human land use is prevalent over most of Honduras, including the Moskitia, the little Amazonia of Central America (Mora et al. 2018). In Honduras it is estimated that only $20 \%$ of the forests remain in a natural state (Galdames et al. 2018). These changes in land use along with climate change are altering the distribution of some species, restricting the habitat of some, and enlarging the habitat of others. There are 59 reptile species endemic to Honduras; several of these species have narrow distributions or are poorly known (McCranie 2018). 


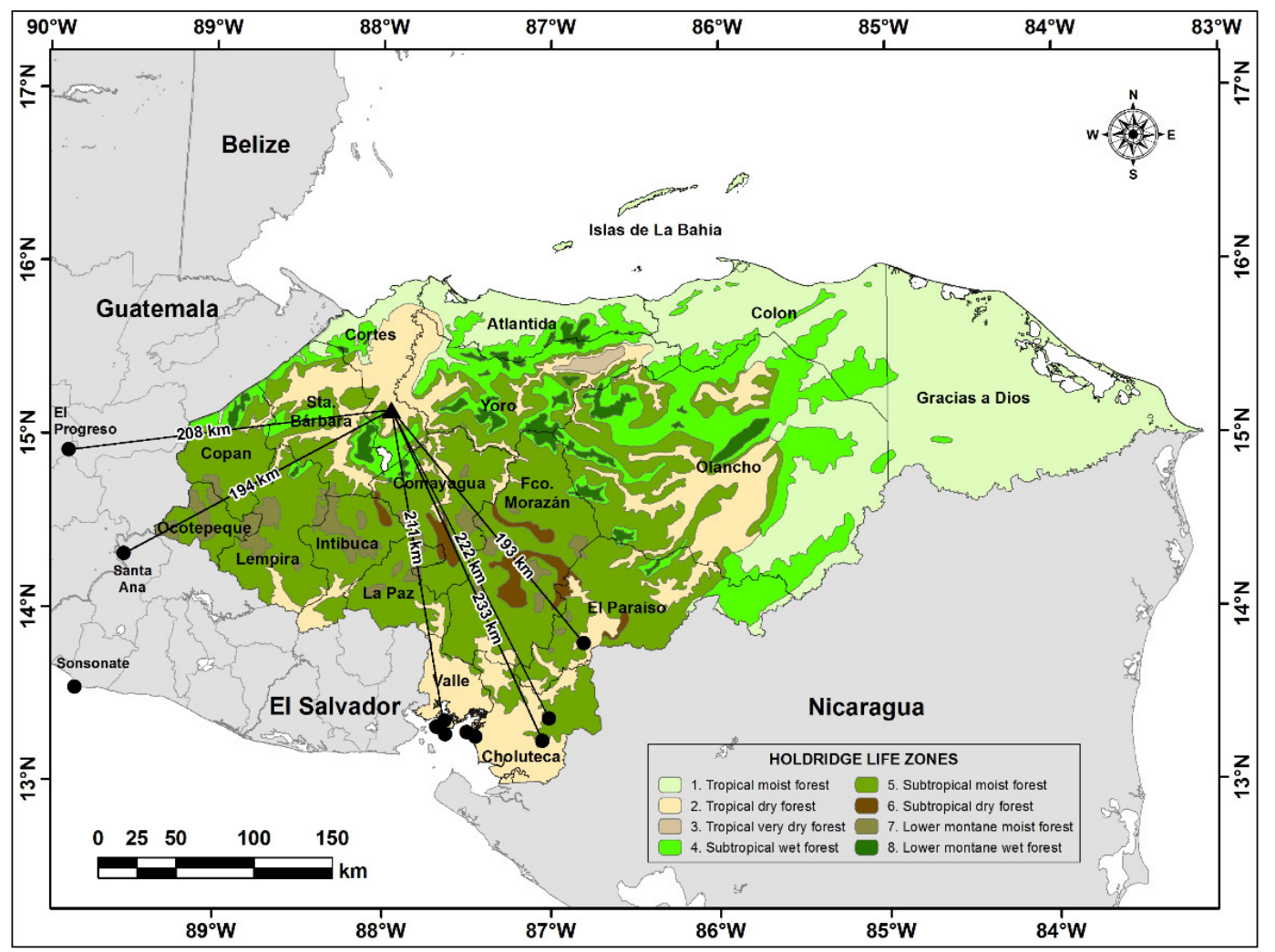

Figure 1. Distributional records for Mesoscincus managuae in Honduras: Previously known localities (black circles) and the new locality (black triangle) at El Caracol, Potrerillos, Cortés, with an indication of the airline distances between the new locality and selected previously recorded ones and nearest distance records from El Salvador and Guatemala.

Mesoscincus managuae (Dunn, 1933) is a species of lizard that is found from near sea level to $920 \mathrm{~m}$ elevation in the Lowland Dry Forest, Lowland Arid Forest, and Premontane Moist Forest formations on the Pacific versant from east-central Guatemala to northwestern Costa Rica, and on the Atlantic versant near Lagos de Managua and Nicaragua in western Nicaragua (Reeder 1990, McCranie 2018). It was first collected in Honduras in 1977 and remained known from this country based on only 2 specimens until recently, when many individuals were found on several islands in the Golfo de Fonseca (McCranie 2018). As a result, M. managuae is now known from several localities in the southern Honduran departments of Choluteca, El Paraíso, and Valle (McCranie 2018). Generally, M. managuae is considered uncommon, but it is often found at sites that are highly modified by humans (Savage 2002). In Honduras, this diurnal species has been taken under logs and rocks, in rock crevices, and basking on tree stumps (Cruz et al. 1979, McCranie 2018). All three species of Mesoscincus have proved to be difficult to find during fieldwork, which results in a poor understanding of their distribution and natural history (Šmek et al. 2007).

One of the results of an inventory of amphibians and reptiles carried out during 2018 in northern Honduras was the finding of 1 individual of M. managuae at a site located on the Caribbean versant of the country, far away from the known distributional range of the species. Here, we report this new locality.

\section{Methods}

During fieldwork on the vehicular impacts on fauna along a road (CA-5 North Highway), amphibians and reptiles were inventoried in the community of Caracol at Potrerillos, Department of Cortés, on the Caribbean versant of Honduras (Fig. 1). The area is used to grow corn under some cultivated trees such as loquat (Eriobotrya japonica), laurel (Cordia alliodora), teak (Tectona grandis), mahogany (Swietenia macrophylla), jobo (Spondias mombin), and mango (Mangifera indica). We captured 1 individual of Mesoscincus managuae, photographed it, and later preserved it using standard procedures for fluid preservation (Pisani 1973). The specimen is vouchered in the zoology museum at the University of Costa Rica (UCR). A collection permit (No. DE-ICF-065-2018) was provided by the Instituto de Conservación Forestal, Tegucigalpa, Honduras.

Occurrence data for M. managuae were obtained from literature (Greenbaum et al. 2002, Savage 2002, Ariano-Sánchez et al. 2010, McCranie 2018). Specimen identification was initially made by comparison with similar specimens and by a literature review (McCraine 2018, Savage 2002). We reviewed 4 specimens of $M$. managuae from the UCR for comparison and confirmation of our specimen's identity. There were no specimens of this species we could review at this time housed at an institution in Honduras. Our identification was verified by Larry D. Wilson and by Gerardo Chavez, curator of herpetology at the UCR. 


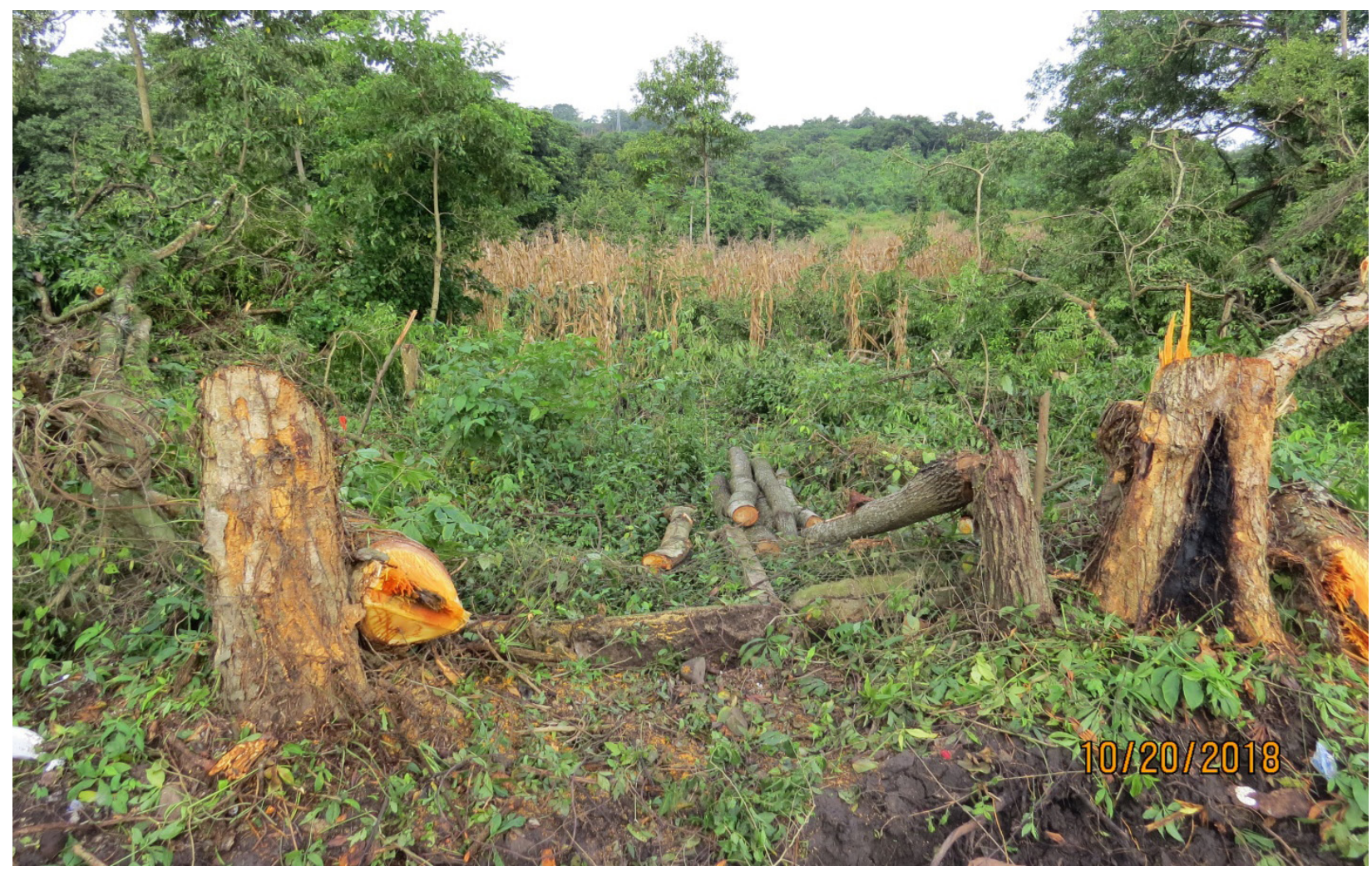

Figure 2. Capture site of Mesoscincus managuae UCR 23168 next to the paved road CA-5 North at El Caracol, Potrerillos, Cortés, Honduras. Photo by M. Espinal.

\section{Results}

Several species were identified on 19 October 2018 at our study site and an individual of Mesoscincus managuae was captured at $1530 \mathrm{~h}$. The individual was captured on the side of a paved road (CA-5 North Highway) at a site where trees had been cut for the widening of this highway (Fig. 2). The animal was captured when it was running on bare soil that had recently been turned over by heavy equipment.

New record. Honduras, Cortés, Potrerillos, El Caracol $\left(15^{\circ} 09^{\prime} 20.7^{\prime \prime} \mathrm{N}, 087^{\circ} 56^{\prime} 56.5^{\prime \prime} \mathrm{W}, 73 \mathrm{~m}\right)$, Mario Roberto Espinal coll., 19 October 2018 (1 adult male, UCR 23168).

Other specimens examined. COSTA RICA: Guanacaste, Carrillo, Sardinal, Ocotal, playa Ocotal $\left(10^{\circ} 32^{\prime} 49.92^{\prime \prime}\right.$ N, $085^{\circ} 43^{\prime} 40.08^{\prime \prime}$ W, $10 \mathrm{~m}$ ), 16 July 1970 (2 adult males, UCR 4528 and 4529); Guanacaste, Santa Cruz, Tempate, Corredor Biológico Diriá, Paraíso, $2.2 \mathrm{~km} \mathrm{E}$ $\left(10^{\circ} 25^{\prime} 09.84^{\prime \prime} \mathrm{N}, 085^{\circ} 41^{\prime} 47.04^{\prime \prime} \mathrm{W}, 100 \mathrm{~m}\right), 24$ June 2005 (1 adult female, UCR 18167); Puntarenas, Puntarenas, Cobano, Reserva Natural Absoluta Cabo Blanco, headquarters area $\left(09^{\circ} 34^{\prime} 42.24^{\prime \prime} \mathrm{N}, 085^{\circ} 06^{\prime} 44.28^{\prime \prime} \mathrm{W}, 300 \mathrm{~m}\right)$, 2003 (1 juvenile, UCR 19758).

Identification. The median row of expanded dorsal scales that extends from the shoulder region to the base of tail distinguishes the genus Mesoscincus in Honduras (McCranie 2018). Our individual of M. managuae (UCR 23168, Fig. 3) matches the unmistackable coloration of this species as described in the literature. This coloration separates this species from other members of the genus, especially from M. schwartzei (Fischer, 1884), which occurs in southern Mexico, Belize, and Guatemala (Percino-Daniel et al. 2012). More technically, our specimen has movable eyelids with no translucent disk in the lower eyelid, the head covered by large plates, a single frontal scale and a single interparietal, the paired supranasals (internasals) in contact medially, 2 frontoparietals, and the body covered by uniform cycloid scales; measurements are: snout-vent length $(\mathrm{SVL})=124 \mathrm{~mm}$, tail length $(\mathrm{TL})=124 \mathrm{~mm}$.

\section{Discussion}

Mesoscincus managuae is of moderate size with a maximum recorded SVL of $125 \mathrm{~mm}$ (in Honduras: previous maximum recorded SVL $=110.0 \mathrm{~mm}$ ) (McCranie 2018). Our individual (UCR 23168; SVL $=124 \mathrm{~mm}$ ) is now the largest individual captured in Honduras.

The new locality for M. managuae is the first on the Caribbean versant of Honduras and extends the known range of this species to the north of the country, ca 193 $\mathrm{km}$ in a straight line from the nearest records in the department of El Paraíso, ca $211 \mathrm{~km}$ from those in Valle, and ca $222 \mathrm{~km}$ and $233 \mathrm{~km}$ from those in Choluteca (Fig. 1). All previous localities are from the dry forests of southern Honduras. The distances between records from Guatemala $(208 \mathrm{~km})$ and El Salvador $(194 \mathrm{~km})$ to the new locality in Honduras reported here are similar to 


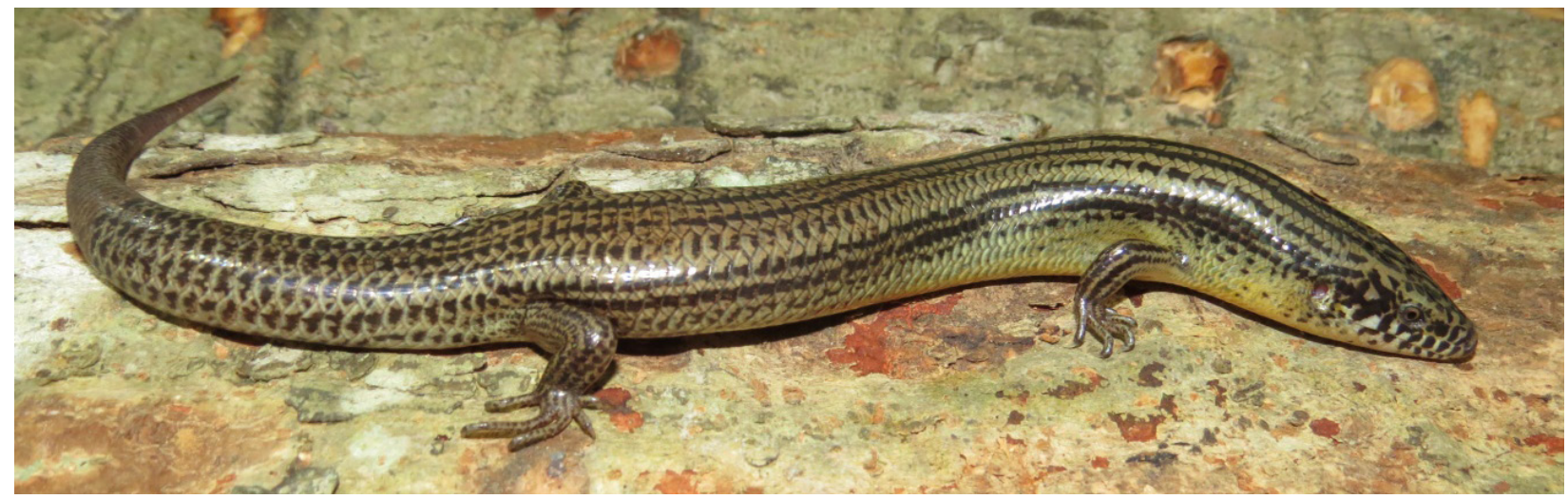

Figure 3. Mesoscincus managuae UCR 23168 from El Caracol, Potrerillos, Cortés, Honduras. Photo by M. Espinal.

the distances between this and previous localities in the south of the country.

Amphibians and reptiles of Honduras are a good example of the diversity and endemism that characterizes the Mesoamerican Hotspot (Solís et al. 2014). With 401 species in Honduras, there is an amazing number of amphibians and reptiles in the country. This is more amazing in that 111 of these are endemic (McCranie 2015). The degree of endemism of the herpetofauna of Honduras is the highest in Central America (Wilson and Johnson 2010). Of the 107 species of lizards that exist in Honduras, 35 are endemic. Several other species have restricted geographic ranges. Mesoscincus manguae has a Mesoamerican distribution, which appears to be primarily restricted to the dry forests of the Pacific versant (McCranie 2018). The mountainous topography and its effect on climate has resulted in an extensive mosaic of ecosystems. For example, some particular associations within the life zones of the country exist in patches such as the Tropical Dry Forest and particularly the Tropical Dry Forest with good soils and presence of dry period (s-T / S1-Ps), according to the Holdridge Life Zones System (Holdridge 1967). It is in this life zone in southern Honduras and on the Atlantic versant of Nicaragua where M. manguae has been found. Although the new record of M. managuae is separated from the other Honduran localities by many mountains and kilometers, its location on the Atlantic slope of Honduras is in the Tropical Dry Forest (s-T / S1-Ps of Holdridge 1967). The capture of the individual in the $\mathrm{s}-\mathrm{T} / \mathrm{S} 1-\mathrm{Ps}$ corroborates that this is a dry-forest species, as reported by other researchers. The atypical, patchy distribution of this species, reflective of the patchiness of some ecosystems, is similarly known for the only endemic bird in Honduras, Amazila luciae (Lawrence, 1868), which is restricted to interior dry valleys of the country (Mora et al. 2016).

Wilson and McCranie (1998) analyzed the herpetofauna of the subhumid forests of Middle America and described the Sula Plain as an extensive north-south structural depression between the Sierra de Omoa and the Cordillera Mico Quemado and Montaña El Tiburón. The subhumid portion of the Sula lower valley lies at elevations from below 100 to about $200 \mathrm{~m}$. The reptilian fauna of this valley belongs to the Middle American Generalized Track, which evolved in situ under the Miocene-Pliocene uplift of the main mountain axis of the area along with the associated climatic changes that gradually fragmented a widespread mesic Middle American herpetofuana into 3 assemblages (Wilson and McCranie 1998). According to this model, $M$. managuae can be expected to occur at the Sula Plain. This means that although the distribution expansion presented herein is extensive, $M$. managuae should probably not be expected to occur everywhere between the known occurrences but instead will likely be found to be very restricted to the subhumid habitats as predicted and described by Wilson and McCranie (1998).

There is still much to learn about $M$. managuae. It is presumed to be oviparous, diurnal, and terrestrial, and it has been found mainly under rocks (McCranie 2018). The first report of this species in Honduras was based on a specimen found under a rock pile in a disturbed area behind a house (Cruz et al. 1979). One individual, collected more recently in Orealí, El Paraíso, was found under a large rock in scrubby vegetation on a hillside used for crops of corn and mango (McCranie et al. 2014); these researchers reported that the lizard disappeared several times by crawling under adjacent rocks when chased and that it was finally caught from under the rock where they had first sighted it (McCranie 2018). One individual in Guatemala was found under a rock in heavily degraded subtropical thorn-scrub forest (Šmek et al. 2007). A juvenile was found under a fallen termite nest in disturbed forest at León, Nicaragua (Sunyer and Köhler 2007). The first country record for El Salvador was an individual found under a log in tropical dry forest (Greenbaum et al. 2002). The first documented locality for Guatemala was 1 individual that crawled through a dry gulley in Tropical Dry Forest (Ariano-Sánchez et al. 2010). Besides these reports, practically nothing else is known about this species.

Our new data comprises 3 main contributions to the knowledge of M. managuae: a new record at the departmental level (Cortés; Fig. 1), an extension of the species' geographic range by about $200 \mathrm{~km}$ from the nearest previously known occurrence, and a new northernmost 
record of the species. Our record is also from a subhumid habitat but on the Caribbean versant of Honduras. Our new data on $M$. managuae demonstrates that increased efforts are needed to better know the geographic distribution of Honduras's biodiversity.

\section{Acknowledgements}

We thank Larry D. Wilson for confirming our specimen's identity as well as for providing advice and corrections regarding the manuscript. We are grateful to Gerardo Chavez for confirming our identification and for providing data of and access to specimens at the UCR collection. José Mario Solis provided the measurements of the specimen. We thank Jorge Luis Funez Medina for preparation of the map and Profesionales de la Construcción (PRODECON) for financing the fieldwork. Sebastian Lotzkat and Javier Sunyer, as well as Robert Forsyth, made valuable comments and suggestions for the improvement of the manuscript.

\section{Author contributions}

ME found the specimen at the new locality (Cortés) and collected the data; JM reviewed specimens at UCR and elaborated the manuscript. JM and ME studied maps of Holdridge Life Zones to determine the ecosystem of collected individuals. Both authors read, edited, and approved the manuscript.

\section{References}

Ariano-Sánchez D, Urbina A, Salazar G (2010) Geographic distribution. Mesoscincus managuae (Managua Skink). Herpetological Review 41: 107.

Cruz GA, Wilson LD, Espinosa J (1979) Two additions to the reptile fauna of Honduras, Eumeces managuae Dunn and Agkistrodon bilineatus (Gunther [sic]), with comments on Pelamis platurus (Linnaeus). Herpetological Review 10: 26-27.

Escobar-Anleu BI, Quiñónez-Guzmán JM, Mora JM (2018) Filling distribution gaps of a little-known endemic species, Rojasianthe superba Standl. \& Steyerm. 1940 (Asteraceae) in northern Central America. Check List 14 (1): 267-275. https://doi.org/10.15560/ 14.1.267

Galdames JA, López LI, Mora JM, Ulloa NS (2018) Camino hacia un país megadiverso: áreas naturales de importancia para la biodiversidad de Honduras. MiAmbiente+, Tegucigalpa, Honduras. 268 pp.

Greenbaum E, Herrera N, Ibarra Portillo R, Komar O, Rivera R (2002) Geographic distribution. Mesoscincus managuae (Managua Skink). Herpetological Review 33 (4): 322

Holdridge LR (1967) Life Zone Ecology. Tropical Science Center, San José, Costa Rica, 206 pp.

Magrin G, Gay García C, Cruz Choque D, Giménez JC, Moreno AR, Nagy CG, Nobre C, Villamizar A (2007) Latin America. Climate Change 2007: impacts, adaptation and vulnerability. In: Parry ML, Canziani OF, Palutikof JP, van der Linden PJ, Hanson CE
(Eds) Contribution of Working Group II to the Fourth Assessment Report of the Intergovernmental Panel on Climate Change. Cambridge University Press, Cambridge, 581-615.

McCranie, JR (2015) A checklist of the amphibians and reptiles of Honduras, with additions, comments on taxonomy, some recent taxonomic decisions, and areas of further studies needed. Zootaxa 3931: 352-386. https://doi.org/10.11646/zootaxa.3931.3.2

McCranie JR (2018) The Lizards, Crocodiles, and Turtles of Honduras. Systematics, Distribution, and Conservation. Bulletin of the Museum of Comparative Zoology. Special Publications Series, No. 2. Harvard University, Cambridge, Massachussetts, 666 pp.

McCranie JR, Dionicio R, Ramos J, Valdés Orellana L, Merida JE, Cruz GA (2014) Eight new departmental records of lizards and snakes (Reptilia: Squamata) from subhumid areas in El Paraíso, Honduras, and morphometry of the poorly known pitviper Agkistrodon howardgloydi. Cuadernos de Investigació, UNED Research Journal 6: 99-104.

Mittermeier RA, Robles Gil P, Hoffman M, Pilgrim J, Brokks T, Mittermeier CG, Lamoreux J, da Fonseca GAB (2004) Hot Spots Revisited-Earth's Biologically Richest and Most Endangered Terrestrial Ecoregions. CEMEX S.A de C.V. México, México DF, $432 \mathrm{pp}$.

Mora JM, Espinal MR, Germer LD, López LI (2016) Abundancia relativa del colibrí esmeralda (Amazilia luciae) en su comunidad de aves en el Valle de Agalta, Olancho, Honduras. Ceiba 54 (2): 127-138. https://doi.org/10.5377/ceiba.v54i2.3284

Mora JM, López LI, Espinal M, Marineros L, Ruedas L (2018) Diversidad y conservación de los murciélagos de Honduras. MiAmbiente+, Tegucigalpa, Honduras. 284 pp.

Percino-Daniel R, Bárcenas Arriaga S, Sarabia Rangel A (2012) Ampliación de la distribución de Mesoscincus schwartzei (Squamata: Scincidae) en el Estado de Chiapas, México. Acta Zoológica Mexicana 28 (3): 644-648. https://doi.org/10.21829/azm.2012.283870

Pisani GR (1973) A Guide to Preservation Techniques for Amphibians and Reptiles. Society for the Study of Amphibians and Reptiles. Miscellaneous Publications, Herpetological Circular No. 1. University of Kansas, Lawrence, Kansas, 22 pp.

Reeder, TW (1990) Eumeces managuae. Catalogue of American Amphibians and Reptiles 467: 1-2.

Savage JM (2002) The Amphibians and Reptiles of Costa Rica. A Herpetofauna between Two Continents, between Two Seas. The University of Chicago Press, Chicago, Illinois, 934 pp.

Šmek P, Uetz P, Pavón-Vázquez CJ (2007) Range extension of Mesoscincus managuae (Dunn, 1933) in Guatemala. Mesoamerican Herpetology 4 (4): 955-958.

Solís JM, Wilson LD, Townsend JH (2014) An updated list of the amphibians and reptiles of Honduras, with comments on their nomenclature. Mesoamerican Herpetology 1 (1): 123-144.

Sunyer J, Köhler G (2007) New country and departmental records of herpetofauna in Nicaragua. Salamandra 43: 57-62.

TRAGSATEC (2016) Análisis Forestal de Honduras. Proyecto EuroFor-Mosef. Unión Europea. Instituto de Conservación Forestal, Tegucigalpa, Honduras, $60 \mathrm{pp}$.

Wilson LD, Johnson JD (2010) Distributional patterns of the herpetofauna of Mesoamerica, a biodiversity hotspot. In: Wilson LD, Townsend JH, Johnson JD (Eds.) Conservation of Mesoamerican Amphibians and Reptiles. Eagle Mountain Publishing, LC, Eagle Mountain, Utah, 30-235.

Wilson LD, McCranie JR (1998) The biogeography of the herpetofauna of the subhumid forests of Middle America (Isthmus of Tehuantepec to northwestern Costa Rica). Royal Ontario Museum, Life Sciences Contributions 163: 1-50. https://doi.org/ 10.5962/bhl.title. 53485 